\title{
The Sexuality of Malcolm X
}

\section{Christopher Phelps}

\author{
(C) 2015, 2016 Christopher Phelps \\ The moral rights of the author have been asserted \\ No permission to quote or reproduce without permission
}

This article was first submitted to a journal in September 2015.

The date of the present version is June 22, 2016.

Accepted for publication in the Journal of American Studies (Cambridge University Press)

Publication to occur in 2017

\author{
Christopher Phelps \\ American and Canadian Studies \\ University of Nottingham \\ University Park \\ Nottingham, NG7 2RD \\ U.K. \\ US voicemail: 7135880779 \\ UK office number: 01159514211 \\ christopher.phelps@nottingham.ac.uk
}




\title{
The Sexuality of Malcolm X
}

\author{
Christopher Phelps*
}

ABSTRACT This article engages the controversy over whether Malcolm Little, who would become Malcolm X, had same-sexual encounters. A minute sifting of all evidence and claims, augmented by new findings, yields strong indication that Malcolm Little did take part in sex acts with male counterparts. If set in the context of the 1930s and 1940s, these acts position him not as a "homosexual lover," as has been asserted, but in the pattern of "straight trade"—heterosexual men open to sex with homosexuals—an understanding that in turn affords insights into the black revolutionary's mature masculinity.

"More power to him," a Harlem waitress told an Ebony reporter in 1964, referring to Malcolm X. "I'm sick and tired of Martin Luther King's turn-the-other-cheek stuff. What has it gotten us? Malcolm X is a real man because he stands up for what he believes." If favoring Malcolm over Martin would shock most readers of Ebony at the height of the civil rights movement, the next ten years saw ever-wider embrace of Malcolm X as "real man." The Autobiography of Malcolm X (1965) as told to Alex Haley chronicled his lifting of himself up from degradation, crime, and prison to achieve selfmastery, assert black dignity, and refine his searing elocution. In Malcolm X's selfportrayal, his moral rebirth was inseparable from race radicalism, personal responsibility being a predicate for dressing down white America and Uncle Tom "house Negroes." When Ossie Davis eulogized Malcolm X as "our shining black prince" and defined "his

\footnotetext{
* Department of American and Canadian Studies, University of Nottingham. Email: christopher.phelps@nottingham.ac.uk.
} 
meaning to his people" as "our manhood, our living black manhood," his reputation was sealed as the epitome of blackness and masculinity. ${ }^{1}$

The hyper-masculinity of Black Power spokesmen in the late sixties owed much to a self-conception of picking up where Malcolm left off, their bravado in turn giving rise to a black feminism that challenged what Angela Davis, at the peak of 1990s hip-hop Malcolmania, would call "notions of male dominance in this contemporary iconization of Malcolm X." ${ }^{2}$ Some black feminists hypothesized that in the metamorphosis of his final year Malcolm moved toward inclusiveness of women on an equal basis, but attachment to Malcolm X as a supremely masculine role model—admired by figures as various as Clarence Thomas and Barack Obama—would endure as manufacturing's flight, budget cuts, and mass incarceration combined with the drug trade, low high-school graduation rates, gangsta culture, and "babies having babies" to create what many termed a crisis of black male youth. Malcolm X's urban edge, personal discipline, and "by any means necessary" militancy made him, wrote the novelist David Bradley, "an African-American hero, when the demand for such is great and the supply of same short."3

Esteem for Malcolm X as an icon of masculinity, not only blackness or revolution, helps explain why such a storm of criticism met Manning Marable's Malcolm X: A Life of Reinvention (2011), with its claim that Malcolm Little, as he was named in his youth,

\footnotetext{
${ }^{1}$ Hans J. Massaquoi, "Mystery of Malcolm X," Ebony (Sept. 1964), 41-42; Ossie Davis, "Our Shining Black Prince," in John Henrik Clarke, ed., Malcolm X: The Man and His Times (Toronto: Macmillan, 1969), xii.

${ }^{2}$ Angela Y. Davis, "Meditations on the Legacy of Malcolm X," in Malcolm X: In Our Own Image, ed. Joe Wood (New York: St. Martin's, 1992), 42.

${ }^{3}$ David Bradley, “Malcolm's Mythmaking," Transition, vol. 2, no. 56 (1992), 35.
} 
was a "homosexual lover." ${ }^{4}$ Published days after his death, Marable's biography was praised by Ivy League stars from Henry Louis Gates to Cornel West and awarded the Pulitzer Prize even as other black scholars, radicals, and nationalists issued a torrent of objections to it. Special journal issues, edited collections, and dozens of reviews faulted the book, its claim of homosexuality eliciting perhaps the most voluble indignation. ${ }^{5}$

That proposition actually dated back three decades, but it became a flashpoint with Marable's book because there for the first time it was advanced by a leading African-American historian and disseminated by a major publishing house. The specific uproar over Marable's book having now abated, clarification might be facilitated by refocusing on the life of Malcolm Little in the Great Depression and Second World War. The question of same-sexuality in his experience deserves a dispassionate, thorough analysis given that it is germane to scholarly interest in race and sexuality, the contrapuntal relationship between the movements for black self-determination and same-sex equality, and the life of this black revolutionary of world-historical importance.

\footnotetext{
${ }^{4}$ Manning Marable, Malcolm X: A Life of Reinvention (New York: Viking, 2011), 78.

5 “A Forum on Manning Marable's Malcolm X: A Life of Reinvention," The Black Scholar, vol. 41, no. 2 (summer 2011), 2-32; Jared A. Ball and Todd Steven Burroughs, eds., A Lie of Reinvention: Correcting Manning Marable’s Malcolm X (Baltimore: Black Classic, 2012); Herb Boyd, Ron Daniels, Maulana Karenga, and Haki R. Madhubuti, eds., By Any Means Necessary: Malcolm X: Real, Not Invented (Chicago: Third World, 2012); "Reflections on the Legacy of Malcolm X," Journal of African American History, vol. 98 (fall 2013), 562-606. An able survey of the controversy is provided by Joe Street, "Roundtable: Manning Marable, Malcolm X: A Life of Reinvention," Journal of American Studies, vol. 47, no. 1 (2013), 23-35.
} 
This article seeks to sift all evidence that has led some to conclude that Malcolm Little had same-sexual encounters. By necessity this procedure is detailed and explicit. The point is not to engage in voyeurism but to consolidate understanding and devise a viable interpretation. The evidence is arrayed comprehensively in the order of its surfacing, set within the unfolding secondary literature on Malcolm X, and subjected to scrutiny, with new findings conveyed. This process yields strong indication that Malcolm Little did take part in sex acts with male counterparts, if not photographic or confessional proof of the kind skeptics appear to demand. A new analysis of the meaning of these acts follows that draws on secondary literatures and primary sources on sexual identity, male sex work, and race and sexuality. It shows that in the context of the 1930s and 1940s the form of same-sex activity that Malcolm Little took part in, far from making him a "homosexual lover," fit patterns consistent with heterosexuality, as counterintuitive as that may seem today. This "straight trade" status, in turn, provides insight into the later masculinity of Malcolm X, revealing significant continuities in gender outlook between his adolescent and mature selves alongside the moral transformation so heavily underscored in The Autobiography of Malcolm X. The result is to affirm that sexuality has a history, one best understood by recourse to its historiography, while substantiating a point made recently by Sharon Marcus, namely that "the sexualities we consider normal and think we know best are consequently those we understand the least." ${ }^{6}$

\footnotetext{
${ }^{6}$ Sharon Marcus, “Queer Theory for Everyone: A Review Essay," Signs 31 (2005), 213.
} 
All assertions of Malcolm's same-sexual involvement concern the years prior to his prison term, conversion to the Nation of Islam, and emergence as Malcolm X: the period when he was still named Malcolm Little. First to broach the subject was the writer Bruce Perry, initially in an obscure 1985 journal article and then, more controversially, in Malcolm: The Life of a Man Who Changed Black America (1991). ${ }^{7}$ Perry's findings came wrapped in a pejorative psychoanalytic framework that won little acclaim, but any full inventory of Malcolm's sexuality requires appraisal of his research, not least because Perry sought out a great number of Malcolm's friends and acquaintances from his youth as sources.

Malcolm Little was born in 1925 in Omaha, Nebraska, but the family moved soon afterward to Milwaukee, Wisconsin, and then in 1928 to Lansing, Michigan. There in 1931 when Malcolm was six, his father Earl Little, a Marcus Garvey admirer, died in a streetcar accident that the family conjectured was a murder by white supremacists, leaving them impoverished and struggling in a mostly white working-class neighborhood. Decades later, Perry contacted many of their surviving Lansing acquaintances. Bob Bebee-a friend of Malcolm's who was a "short, freckle-faced redhead"- -told Perry that he and Malcolm had sex with a white neighbor girl outside the Nazarene church late one night. Malcolm, panicky, urged Bebee to withdraw before he

\footnotetext{
${ }^{7}$ Bruce Perry, "Malcolm X and the Politics of Masculinity," Psychohistory Review, vol. 13, nos. 2-3 (1985), 18-25; Bruce Perry, Malcolm: The Life of a Man Who Changed Black America (Barrytown: Station Hill, 1991). Two prior articles focus less on sexuality: Bruce Perry, "Escape from Freedom, Criminal Style, The Hidden Advantages of Being in Jail," The Journal of Psychiatry \& Law, vol. 12, no. 2 (summer 1984): 215230; Bruce Frazier Perry, "Malcolm X in Brief: A Psychological Perspective," The Journal of Psychohistory, vol. 11, no. 4 (1984), 491-500.
} 
made her pregnant. After Bebee finished, he coaxed the girl into having sex with Malcolm as well. On another occasion, Bebee and Malcolm encountered a boy they knew named Robert in the woods. Robert was "tall, broad-shouldered, and muscular," writes Perry, "the very image of the all-American boy," but "also effeminate and considered a sissy." He was the rebellious son of "puritanical" parents, his brother "the apple of their eye." Earlier, Malcolm came across Robert masturbating, and that day Malcolm directed him to do it again. "He wanted me to see Robert's huge phallus," said Bebee. Then Malcolm "instructed him to masturbate him," and Robert complied. Subsequently Malcolm told Bebee that "Robert had performed fellatio on him," and "Bob had no reason to doubt his friend, for Robert had yielded similarly to him." ${ }^{8}$

If these accounts are true, then some of Malcolm's earliest adolescent sexual experiences included intercourse with a white girl and genital stimulation by a white boy. The positioning of the stories in Perry's narrative, combined with Malcolm's anxiety about impregnation, suggest a timing of around 1937 or 1938 in East Lansing, when Malcolm was thirteen or fourteen, between when his mother Louise Little became pregnant and was abandoned by her boyfriend and her institutionalization for madness in December 1938. A few months before, Malcolm was expelled from his Eastside school in the seventh grade and taken in by a white foster family in West Lansing at age

\footnotetext{
${ }^{8}$ Perry, Malcolm, 16, 28-29; see also "Malcolm X and the Politics of Masculinity," 20. The passage mentions only Bob Bebee as source for this story, but the endnotes (p. 396) also credit an interview with Ray Bebee, his brother. The surname of the boy in the woods, Robert, is never stated. The correspondence of the names Bob and Robert, combined with the intimacy with which Robert's family is described, down to the two brothers, hints that Bebee might actually have been "Robert," although their physical descriptions do not match.
} 
thirteen so he could attend a new school. In the next three years, he would sometimes return home to the disintegrating Little household, headed momentarily by his nineteenyear-old brother; be placed by the state in a juvenile home in Mason ten miles to the south; and live briefly in two black foster homes in Lansing. A visit from his half-sister Ella Collins—who sensed his plight and impressed Malcolm as "the first really proud black woman I had ever seen in my life"—resulted in her sponsoring a summer 1940 visit to her home in Boston, Massachusetts, and gaining permanent custody of him, when he was fifteen, in February 1941. Living with her in Roxbury, Boston's AfricanAmerican district, and working in a drug store, on railways, and at an assortment of other jobs, Malcolm entered his storied zoot-suit phase. ${ }^{9}$

In that period Malcolm had additional same-sex encounters, according to Perry, who also confirmed that Malcolm avidly pursued women and embarked on a series of hustles that included steering white male customers to female black prostitutes in Harlem, as is consistent with The Autobiography of Malcolm X. When Malcolm returned to Michigan at age seventeen to take up work at Christmas 1942 in an AC Sparkplug factory in Flint, a stint lasting only a few months, he stayed at the rooming house of Delia Williams, writes Perry: "One of Malcolm's roommates had jokingly suggested that he might be able to raise some rent money by striking a deal with a fellow boarder called 'Miss Jones.' Shortly thereafter, the roommate began noticing that Malcolm wasn't sleeping in the room they had been sharing. Instead, he began stealing down the hallway to Miss Jones's room. But Miss Jones, who sported a bright yellow jumper with matching slacks and umbrella, was not a woman. He was a well-known transvestite

\footnotetext{
${ }^{9}$ The Autobiography of Malcolm X (1965; New York: Grove, 1966), 32.
} 
named Willie Mae. Malcolm's roommate concluded that Willie Mae was sleeping with him." 10

Returning east in March 1943, Malcolm would spend most of the next three years, between ages seventeen and twenty, living in Harlem and Boston. In New York one night, writes Perry, Malcolm ran into two Michigan friends who had joined the merchant marine and were visiting New York at the YMCA. They asked what he was doing there. "Hell, with all these little 'girls' here, I'm going to make some money," he replied. Malcolm later told them about two "queers" at the Harlem YMCA willing to pay. "It's not that bad," he said. "They suck dick!" He then, writes Perry, "arranged a 'party' in the six-by-nine-foot YMCA cubicle of a man who called himself 'Reverend Witherspoon.' The arrangements were businesslike. Each man closeted himself with Witherspoon and emerged, minutes later, with an embarrassed grin on his face." Witherspoon promised chicken dinners in return. ${ }^{11}$

The return of Malcolm to Massachusetts in October 1944 led to the episode that would resonate most in scholarship subsequent to Perry. [INSERT FIGURE ONE SOMEWHERE ON PAGE FROM HERE ON OR SO, DELETE THIS BRACKET] This concerned William Paul Lennon, "a wealthy Boston Brahmin whose living quarters overlooked the Boston Common," for whom Malcolm worked in household tasks. Malcolm Jarvis, basis for the character "Shorty," Malcolm's best friend in The Autobiography of Malcolm X, told Perry that Malcolm had said Lennon paid him and another man "to disrobe him, place him on his bed, sprinkle him with talcum powder,

\footnotetext{
${ }^{10}$ Perry, Malcolm, 77. See also "Malcolm X and the Politics of Masculinity," 20.

${ }^{11}$ Perry, Malcolm, 77. See also "Malcolm X and the Politics of Masculinity," 20.
} 
and massage him until he reached his climax." ${ }^{12}$ This echoes a homoerotic passage in the Autobiography referring to "Rudy," a friend of Shorty and Malcolm's identified as being of black and Italian parentage:

Rudy worked regularly for an employment agency that sent him to wait on tables at exclusive parties. He had a side deal going, a hustle that took me right back to the old steering days in Harlem. Once a week, Rudy went to the home of this old, rich Boston blueblood, pillar-of-society aristocrat. He paid Rudy to undress them both, then pick up the old man like a baby, lay him on his bed, then stand over him and sprinkle him all over with talcum powder.

Rudy said the old man would actually reach his climax from that. ${ }^{13}$

According to Jarvis, two men actually took part in these powderings. In a footnote, Perry supplied a letter from Jarvis, reproduced without correction: "People like Paul Lennerd, the queer, always liked to see a new face on the scene every now and then. After meeting Paul Lennerd and participating ina few of the parties, Malcolm confided in me about the affair. As I look back in the years, I believe today that Malcolm's idea in telling me all this was to get me to join the party as a new face on the scene, and make a few easy dollars on the side while doing so... It was the practice of Mr.—or Mrs. (smile)— Lennard to pay for your time if it was satisfying." 14

The final allusion to homosexuality in Perry comes after Malcolm's November 1944 arrest in Boston for theft of a fur coat, which prompted him to return to Lansing to wait tables and bus dishes. There, writes Perry, Malcolm lived with a "240-pound homosexual named Jimmy Williams, who supplied him with bed and board." Malcolm turned on Williams, robbing him at gunpoint, but Williams stuck by him and gave him a

\footnotetext{
${ }^{12}$ Perry, Malcolm, 82-83.

${ }^{13}$ The Autobiography of Malcolm X, 140 .

${ }^{14}$ Perry, Malcolm, 414.
} 
job making mattresses at the Capitol Bedding Company where Williams was a supervisor, employment that Malcolm would quit in July 1945 to return to Boston. ${ }^{15}$

To recapitulate, Perry's book attested primarily to Malcolm's sexual involvement with women but also suggested ties with five homosexual counterparts: Robert (Lansing), Willie Mae (Flint), Reverend Witherspoon (Harlem), William Paul Lennon (Boston), and Jimmy Williams (Lansing). These associations vary in intensity. One is merely a roommate (Jimmy Williams); another (Willie Mae) was sensed by a housemate to be Malcolm's sexual partner. More categorical are the earliest episode (the masturbation and fellatio with Robert), witnessed by a named source, and the remaining two (Reverend Witherspoon and William Paul Lennon), each of whom hired Malcolm for what Perry terms "income-producing homosexual activity."16

Yet in the Malcolm X renaissance of the 1990s, few took these claims seriously, largely because Perry was a white writer perceived to be maladroit at African-American history. He graduated with a degree in economics from Bates College in Maine in 1958, enrolled in Harvard Law School in 1958-59 and again in 1961 without completing a degree, and finally obtained a Ph.D. in international relations from the University of Pennsylvania in 1968 with a dissertation on Senator J. William Fulbright. The cover of Malcolm states that Perry taught political science at universities in Texas and Pennsylvania, but after the book's publication, he vanished from public view. ${ }^{17}$

\footnotetext{
15 "Malcolm X and the Politics of Masculinity," 20. See also Perry, Malcolm, 85-86.

${ }^{16}$ Perry, Malcolm, 83.

${ }^{17}$ If alive, Perry would now be approximately 80; despite sending communications to his three alma maters, publisher, and known past addresses, this writer has been unable to determine his present-day whereabouts. Bruce Perry, "Senator J. William Fulbright on European and Atlantic Unity" (Philadelphia,
} 
Malcolm X's radicalism, Perry held, arose from mental instabilities generated by a fractured childhood. In conservative David Horowitz's Heterodoxy, he wrote that Malcolm was plagued by "doubts about his virility" across "a lifetime of selfdestructiveness"; he "projected onto whites his own imperfections, real and imagined." However Freudian, this portrait of Malcolm's mind focused less on sexuality than claims of a harsh parental upbringing and unresolved inner strife over racial identity, but insofar as same-sexuality figured in the mix, it signified aberration. Malcolm's "male-tomale encounters, which afforded him sexual gratification without the attendant risk of rejection by women," wrote Perry, showed his "partial, vacillating flight from women" and "rebellion against his biologically appointed role," being "purchased at a considerable cost in self-esteem." 18

This psychobiography and its casting of Malcolm X's objection to white supremacy as irrational in origin met with a resounding repudiation from AfricanAmerican intellectuals. David Bradley called Perry's approach "a reductive, mechanistic, and ultimately behavioristic interpretation of Malcolm's career" that "cannot be divorced" from "liberal-racist attitudes." A Baltimore Sun columnist called the book a "hatchet job," while Amiri Baraka called it a "calumny." Robin D. G. Kelley faulted Perry for "an incredible ignorance of black culture." John Edgar Wideman proposed that the book be

1968); Catherine Griffiths (Bate College), e-mail to author, 20 Nov. 2015; Tim Driscoll (Harvard University Archives), e-mail to author, 11 Dec. 2015. A profile of Perry with a rare photo of him ran in an Illinois newspaper: Edith Lee, “Malcolm's Legacy Not Black and White," Rockford Register Star, 15 Feb. 1993, $1 \mathrm{C}, 6 \mathrm{C}$.

${ }^{18}$ Bruce Perry, "Blackwash: Behind the Myths of Malcolm X," Heterodoxy, vol. 1, no. 7 (Dec. 1992), 13; Perry, Malcolm, 77-78; Perry, "Malcolm X and the Politics of Masculinity," 20. 
"read as a work of fiction whose every word is suspect," saying Perry had actually written "an autobiography, the tale of his own life." To Hazel Carby, it "could not be a more devastating attempt to undermine the political significance of the life of Malcolm X had it been written by the CIA as an exercise in disinformation." Such fundamental distrust persists to the present. While admitting that the book was denounced in part out of "anger at the very thought of the icon of black manhood sleeping with men," TaNehisi Coates calls Perry's Malcolm X biography "pretty worthless": "big on telepathy and small on skepticism," with its "any claim" to be taken with "a grain of salt."19 A genuine quandary, therefore, exists over how to weigh Perry's evidence of Malcolm Little's same-sexual encounters. He said he interviewed 420 (or "nearly 500")

\footnotetext{
${ }^{19}$ In his reference to homophobic undertones, Coates may particularly have had in mind Baraka, who never repudiated his anti-homosexual writings as LeRoi Jones. David Bradley, "Malcolm's Mythmaking," Transition, vol. 2, no. 56 (1992), 37; Robin D. G. Kelley, "The Riddle of the Zoot: Malcolm Little and Black Cultural Politics During World War II," in Malcolm X: In Our Own Image, 176; Amiri Baraka, "Malcolm as Ideology," in Malcolm X: In Our Own Image, 19; Gregory Kane, "A Detailed but Flawed Biography of Malcolm X," The Baltimore Sun, 22 Dec. 1991, http://articles.baltimoresun.com/1991-1222/news/1991356150_1_malcolm-x-assassination-of-malcolm-bruce-perry ; John Edgar Wideman, "Malcolm X: The Art of Autobiography," in Malcolm X: In Our Own Image, 111; Hazel V. Carby, "Imagining Black Men: The Politics of Cultural Identity," The Yale Review, vol. 80, no. 3 (July 1992), 189; Ta-Nehisi Coates, "The Sexuality of Malcolm X," The Atlantic, 11 April 2011, http://www.theatlantic.com/national/archive/2011/04/the-sexuality-of-malcolm-x/237086/ . Carby's suspicion of Perry as police agent is echoed in Amiri Baraka, "Malcolm as Ideology," 19; and Abdul Alkalimat, "Rethinking Malcolm Means first Learning How to Think: What was Marable Thinking? And How?" in By Any Means Necessary, 39.
} 
of Malcolm's teachers, friends, peers, and family. ${ }^{20}$ Certainly no one else canvassed Malcolm's youthful acquaintances on anywhere near the same scale. ${ }^{21}$ Because most of Perry's oral-history subjects are no longer alive, his book is the only medium affording access to their recollections about Malcolm's early sexual history. By embedding these memories within an overbearing psychoanalytic interpretation, Perry gave subsequent scholars the near-impossible task of determining whether his commitment to detail makes his accounts trustworthy or whether his evident antagonism toward Malcolm X caused him to inflate impressionistic evidence to achieve a portrait that he believed would be damning. Compounding these problems are irregularities in citation. Perry did not date his interviews, although by inference most were conducted in the early 1970 s. Furthermore, anonymity veils many sources. The Flint boarding house tale, for example, is ascribed to "two confidential sources," with a third verifying Willie Mae's homosexuality. The Reverend Witherspoon anecdote cites interviews with "Johnny Davis, Jr., and two confidential sources." The Williams cohabitation story comes from "Vince" (without surname) and one additional, unnamed source. ${ }^{22}$

If such obscurities leave the impression of an amateur sleuth contaminating a historical crime scene, it should be said that few factual errors have been exposed in Perry's work and that he provided named sources for three of his five main stories: Robert in the woods (Bob Bebee and Ray Bebee), Reverend Witherspoon (Johnny Davis, Jr.), and William Paul Lennon (Malcolm Jarvis). A number of Perry's details are

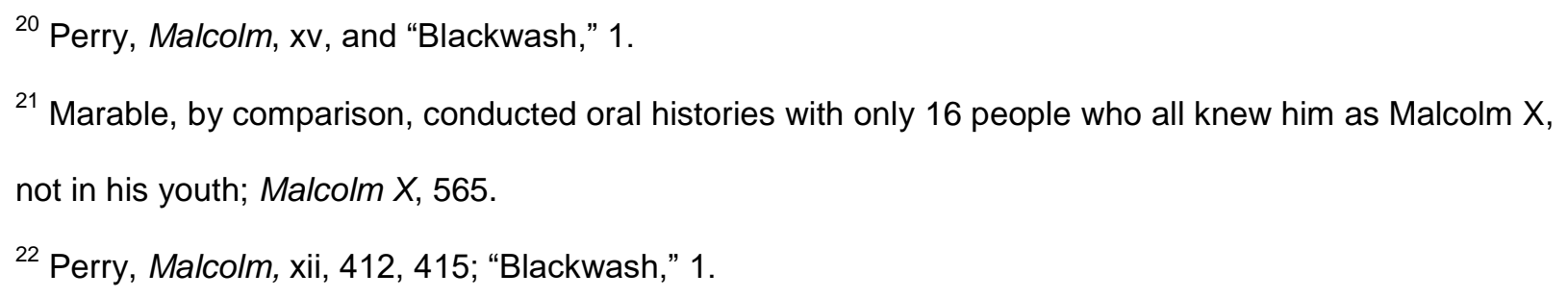


verifiable, moreover. Federal records exist for Michigan residents Robert M. Bebee (1924-1993) and Ray C. Bebee (1927-1989), their lifespans making them Malcolm's contemporaries at puberty and showing that Bob Bebee was alive when Perry's attributions to him were published. The story of sex with the white girl is reminiscent of a passage in The Autobiography of Malcolm X that white boys in Lansing would "push me to proposition certain white girls" since if they broke "the terrible taboo by slipping off with me somewhere, they would have that hammer over the girls' heads, to make them give in to them," although there Malcolm says he declined to do so. The Flint boardinghouse story is substantiated by the 1940 census, which shows Delia Williams, forty, wife of Willie Williams, thirty-one, both Negroes from Arkansas, living at 1614 1/2 Clifford Street, Flint, Michigan, with two lodgers, also Negro. Willie Williams is a striking match for Willie Mae, the alleged "Miss Jones," and his landlord status would square with paying the rent (although it is inconsistent with Willie Mae's description as "another boarder"). That Malcolm Little did work for Paul Lennon, 5 Arlington Street, Boston, as "butler and occ. house-worker," and for the Capitol Bedding Company in Lansing from April to June 1945, are confirmed by his Masachusetts prison file. The Autobiography, finally, refers to "table-waiting" at the "exclusive parties" of a "sensitive old man" and observes that Boston's rich whites "had their private specialty desires catered to by Negroes who come to their homes camouflaged as chauffeurs, maids, waiters, or some other accepted image."23

\footnotetext{
${ }^{23}$ United States Social Security Administration, Social Security Death Index (SSDI); The Autobiography of Malcolm X, 30; United States of America, Bureau of the Census, Sixteenth Census of the United States, 1940 (Washington, D.C.: National Archives and Records Administration); Malcolm Little prison file, Department of Corrections, State of Massachusetts.
} 
In 1991, Perry donated floppy disks related to his book to the Houghton Library at Harvard University, where they are sealed in a vault for fifty years, until 2041. His book states that the disks will divulge his confidential sources' identities. One hopes that a quarter century from now the computer disks will not have deteriorated and technology still exists by which they can be read—or better yet, that the Houghton Library converts the digital files in the interim. What they contain besides the promised list of names is unclear. No other records of Perry's have been donated to any repository. If he or his heirs were to place all his oral history recordings, original notes, and correspondence in a secure archive, it would enable reproducibility of results and foster wider acceptance of his claims of Malcolm's adolescent same-sex experiences. Until that occurs, some will continue to dismiss Perry's research, even if it is perfectly possible to imagine differentiating its factual claims from his interpretations. ${ }^{24}$

As Malcolm X passed from iconoclast to icon, scaling new symbolic and commercial heights in the 1990s through rap music, a Hollywood movie, and X baseball caps, most scholars ignored the question of same-sexuality in his life, just as it was absent from the foundational works of the 1960s and 1970s. Malcolm X: Make it Plain (1994), The Malcolm X Encyclopedia (2002), and The Cambridge Companion to Malcolm X (2010) did not mention it, a sign of antipathy to Perry's work and,

\footnotetext{
${ }^{24}$ Perry did take notes and record interviews: Malcolm, xiii, 382.
} 
undoubtedly, fear of "seeing another black icon torn down, another black hero tarnished. ${ }^{25}$

A few writers were prepared to concede the possibility that Malcolm was sexually involved with other men, albeit guardedly, as when Michael Eric Dyson expressed openness to the idea Malcolm had "homosexual relations" but called Perry's handling of the issue "a rhetorical low blow" that reinforced "a line of attack against an already sexually demonized black leadership culture." ${ }^{26}$ Only one black author-Karl Evanzz of the Washington Post research department, in his book on Malcolm X's assassination The Judas Factor (1992)—stated categorically that Malcolm participated in same-sex acts: "On occasion, when he needed money desperately, Malcolm allowed the men he called 'punks' or 'fags' to perform fellatio on him. It was easy money, and while homosexuals in the African American community have always been treated like lepers, exploiting them as a source of income was viewed as a sign of masculinity." ${ }^{27}$ Evanzz's perception of a uniformly homophobic black community is contradicted by scholarship on the 1930 s and 1940 s suggesting that poor and working-class blacks were more

\footnotetext{
${ }^{25}$ Ron Simmons and Marlon Riggs, "Sexuality, Television, and Death: A Black Gay Dialogue on Malcolm X," Malcolm X: In Our Own Image, 135. See William Strickland, Malcolm X: Make it Plain (New York: Viking, 1994); Robert L. Jenkins, ed., The Malcolm X Encyclopedia (Westport, CT: Greenwood, 2002); and Robert E. Terrill, ed., The Cambridge Companion to Malcolm X (Cambridge: Cambridge, 2010). Key foundational works include George Breitman, The Last Year of Malcolm X: The Evolution of a Revolutionary (New York: Pathfinder, 1967); Clarke, Malcolm X: The Man and His Times; and Peter Goldman, The Death and Life of Malcolm X (New York: Harper and Row, 1973).

${ }^{26}$ Michael Eric Dyson, Making Malcolm: The Myth and Meaning of Malcolm X (New York: Oxford, 1995), 58-59.

${ }^{27}$ Karl Evanzz, The Judas Factor: The Plot to Kill Malcolm X (New York, 1992), 8.
} 
tolerant of homosexuality than white society even as the black middle class, seeking respectability, sought its suppression. ${ }^{28}$ Nevertheless, Evanzz's view that Malcolm's same-sex encounters might be reconcilable with masculinity—indeed, with homophobic utterances-stood out as distinctive. (Evanzz, it should be acknowledged, has since retracted the position that Malcolm had sex with other men and became perhaps the fiercest critic of Marable on this very point. $)^{29}$

Another exception to the silence was Malcolm X: In Our Own Image (1992), edited by the talented Joe Wood. ${ }^{30}$ A nuanced statement of "our own"-that is, AfricanAmerican—voices, the collection paid homage to Malcolm X but exuded a sophisticated

${ }^{28}$ Thaddeus Russell, "The Color of Discipline: Civil Rights and Black Sexuality," American Quarterly, vol. 60, no. 1 (Mar. 2008), 101-128; Kevin Allen Leonard, “Containing 'Perversion': African Americans and Same-Sex Desire in Cold War Los Angeles," Journal of the History of Sexuality, vol. 20, no. 3 (Sept. 2011), 545-567.

${ }^{29}$ The source of Evanzz's claim in The Judas Factor, he believes, was Rodnell Collins, Malcolm X's nephew, relaying something he heard from either Malcolm Jarvis or Ella Collins; Rodnell Collins does not believe Evanzz got the story from him but confirms being told the same thing by Jarvis in a Roxbury park. Jarvis, recalled by both Collins and Evanzz as the source, is independent of the merchant marine seamen credited by Perry for the Reverend Witherspoon New York anecdote, suggesting this as a separate Boston instance of Malcolm as sex worker, although the provenance is obviously murky. Karl Evanzz, emails to author, 17 July 2015, 7 Sept. 2015, and 15 Sept. 2015; Rodnell Collins, interview with author, 20 Sept. 2015. For Evanzz's more recent positions, see “Jared Ball Radio Interview with Karl Evanzz on WPFW 89.3 FM, April 15, 2011," in A Lie of Reinvention, 199-206; and Evanzz, "Paper Tiger," in A Lie of Reinvention, 207-214, also in By Any Means Necessary, 101-106.

${ }^{30}$ The brilliant Yale-educated writer's disappearance at age 34 was a tragic loss for American letters: Kimberly A. C. Wilson, "Birdwatching on Ranier turns fatal for writer, editor Joe Wood," Seattle PostIntelligencer, 31 March 2000, http://www.sarinfo.bc.ca/RainierBirdwatcher.htm. 
ambivalence about blackness as an organizing principle. While many of its contributors abjured Perry's psychoanalysis, giving the volume the quality of a rejoinder to him, they acknowledged that Malcolm's legacy could be marshaled for many subjective purposes, opening onto discussion, among other topics, of whether Malcolm was claimable as gay. Arnold Rampersad noted the "potent revelation" of possible "homosexual relations on Malcolm's part" and cautioned that "homophobia undoubtedly lies behind much of the general supposition that Malcolm could not possibly have had homosexual experiences." ${ }^{31}$ In a sign of abounding uncertainty about Perry and his methods, however, even two openly gay contributors equivocated, calling Malcolm's sexual identity "enigmatic."32

Malcolm X: In Our Own Image contained the most influential essay ever written on Malcolm's adolescence: Robin D. G. Kelley's “The Riddle of the Zoot." Kelley's luminous analysis was that Little's cultural rebellion in the 1940s was progenitor, not antithesis, of his later race radicalism, turning The Autobiography of Malcolm $X$ upsidedown with obvious implications for the hip-hop generation's own politics of style. In a single sentence and footnote, Kelley addressed same-sexuality, calling Perry's evidence "slim, to say the least." This criticism was not entirely evenhanded. Kelley said Perry claimed "Malcolm pimped gay men," apparently in reference to the Reverend Witherspoon story, but there Perry had merely stated Malcolm encouraged friends (not said to be gay) to participate. Kelley also faulted the "hearsay Perry's informant passed

\footnotetext{
${ }^{31}$ Arnold Rampersad, "The Color of His Eyes: Bruce Perry's Malcolm and Malcolm's Malcolm," in Malcolm X: In Our Own Image, 139.

${ }^{32}$ Simmons and Riggs, "Sexuality, Television, and Death," 139.
} 
on," presumably a reference to Jarvis, although Perry's informants were plural and included Bebee, an eyewitness. Louis A. De Caro, Jr. wrote similarly of "shabby, selfserving attempts to homosexualize Malcolm" reliant on "only one source of alleged proof." Both he and Kelley faulted Perry for quoting late-life Malcolm X speeches to make judgments about Malcolm Little's mind in the 1940s, although Perry did that kind of thing only in a footnote-and there more as suggestive traces than proof. In retrospect, the derision of Kelley and De Caro primarily illustrates how the best Malcolm X scholars of the 1990s, put off by Perry's psychobiography, dismissed his evidence. ${ }^{33}$

Shortly thereafter, however, powerful new corroboration of Malcolm's youthful same-sexual activity appeared, particularly in regard to William Paul Lennon. In 1998, Rodnell Collins, son of Malcolm X's half-sister Ella Collins, published a book billed as a memoir that featured quotations from his mother's papers and conversations before her death in 1996. A credited assistant on the project was Peter Bailey, who belonged to the Organization of African American Unity (OAAU) under Malcolm X and edited its newsletter Blacklash. The book quotes Ella Collins as saying that she admired Malcolm's "rebelling against the hypocrisy and racial oppression so prevalent in the United States in the 1940s and 1950s" but "didn't admire his using that rebellious streak against himself by using drugs and throwing away his money on zoot suits and conked hair and against his own people by selling them drugs and directing thrill-seeking whites

\footnotetext{
${ }^{33}$ Kelley, "The Riddle of the Zoot," 169, 181. Louis A. De Caro, Jr., On the Side of My People: A Religious Life of Malcolm X (New York: New York University Press, 1996), 65; Perry, Malcolm, 414. Kelley's essay was much-reproduced, as in Kelley, Race Rebels: Culture, Politics, and the Black Working Class (New York: The Free Press, 1996), 162-181. An important accompaniment is Kelley, "House Negroes on the Loose: Malcolm X and the Black Bourgeoisie," Callaloo, vol. 21, no. 2 (1998): 419-435.
} 
to places where they could indulge in their kinky sexual fantasies with weak, moneymad black folks. ${ }^{34}$

Most strikingly, the book introduced a letter Malcolm wrote from prison to Ella Collins on September 10, 1946: "The person that you said called me is a very good friend of mine. He's only worth some fourteen million dollars. If you read the society pages you'd know who he is. He knows where I am now because l've written and told him, but I didn't say what for. He may call and ask you. Whatever answer you give him will have to do with my entire future but I still depend on you..." She assumed that Malcolm was seeking to facilitate parole by manipulating "one of those decadent whites whom he had been hustling." When she visited him in prison, her son writes, Malcolm told her about "a business deal he and Malcolm Jarvis had with an elderly, wealthy white millionaire named Paul Lennon, who would pay them to rub powder over his body" and said that "Lennon's current powderer was Frank Cooper, who had sometimes visited him with...Malcolm and Jarvis." However, this "friend"—Lennon—“never called again." 35

Although few apart from ardent Malcolm X aficionados read the Collins book, but its contribution of a previously unknown letter of Malcolm's was significant, as was its placement of family members (Ella Collins and her son) on record for the first time in

\footnotetext{
${ }^{34}$ Rodnell Collins with A. Peter Bailey, Seventh Child: A Family Memoir of Malcolm X (Secaucus: Carol, 1998), 41. Such Ella Collins quotations were verbatim from tapes: Rodnell Collins, interview with author, 20 Sept. 2015.

${ }^{35}$ Collins, Seventh Child, 71, 76. Neither the 1946 letter from Malcolm in prison nor Ella Collins's tapes and notes have been placed in an archive accessible to scholars; if the Collins family did so, it would make this record more verifiable.
} 
favor of Jarvis's memory that Malcolm was involved in the Lennon powdering. One of its details, moreover, is verifiable: the existence of Frank Cooper, a Roxbury resident sentenced at age 23 in May 1946 to 9-12 years in prison for assault. (That incarceration means he could no longer have been Lennon's powderer when Malcolm wrote to Collins, but Malcolm, imprisoned, might very well not have heard that news. $)^{36}$

A Malcolm Jarvis memoir appeared posthumously in 2001, following his 1998 death. In it he did not mention Paul Lennon but alluded to "many things Malcolm never told Alex Haley," saying, "I feel those things Malcolm never intended to become public news. I too shall respect Malcolm's wishes in this manner." Jarvis regretted collaborating with an author (Perry, evidently) whose book brought scorn on him in the black community after a false promise of monetary compensation. ${ }^{37}$ Burnt by that

\footnotetext{
${ }^{36}$ Rodnell Collins names Little, Cooper, and Jarvis as being involved in the Lennon powderings, but supplies no evidence for including Jarvis. Cooper and Little are the most likely participants because Jarvis named the other two, not himself, leading Perry to state only that Little and "another man" took part. Perry, Malcolm, 82; "Sentenced for Attack," Boston Herald, 21 May 1946, 8.

${ }^{37}$ Jarvis wrote that his own "association with Malcolm, post-prison, has always been spirituality-based, not monetarily-based," but that he was "once falsely accused by someone close to him of selling him down the river for money... because I collaborated on a book about Malcolm. I did so out of the goodness of my heart and a deep, abiding respect for Malcolm X and all that he advocated. I was promised $\$ 500$ and was never paid. The money was supposed to compensate me for my time invested. From the names I was called, you'd think I tried to rob the Brinks. I was called 'a damn fool and an ass'... Well, maybe I was, but my intentions were honorable." Malcolm "Shorty" Jarvis with Paul D. Nichols, The Other Malcolm — "Shorty" Jarvis: His Memoir, ed. Cornel R. West (Jefferson, NC, and London: McFarland, n.d. [2001]), 132-136.
} 
experience, Jarvis seems not to have discussed Lennon on the record with anyone else, but he never denied anything Perry attributed to him. ${ }^{38}$

In 2005, the question of Malcolm and same-sexuality was catapulted into the Internet age in a Guardian article by Peter Tatchell claiming Malcolm as gay icon. A longtime British gay rights campaigner, Tatchell drew solely on Bruce Perry's biography to hold that Malcolm had "sex for money" and "at least one sustained sexual liaison with a man" and to suggest that "some degree of queer desire" must have enabled "Malcolm to sustain his sexual experiences with men over a period of ten years." Given Malcolm's age of twenty when incarcerated, this dated his first same-sexual experience before he was ten, which no one else had suggested. In that and two other pieces, Tatchell cast the Nation of Islam as custodian of Malcolm's legacy when in actuality the two ended as

${ }^{38}$ Evanzz seeks to explain away Jarvis's attestation that Malcolm Little was involved in the Lennon powdering by saying he fabricated that claim maliciously, out of resentment toward Malcolm for leading police to him in 1946. This is unpersuasive. Little's prison file does show he cooperated with detectives after they offered to drop a gun-possession charge if he named accomplices, but there is no evidence Jarvis ever knew it. Jarvis's own prison file includes reports from authorities stating that he "attributes his present offense to his own stupidity," believing his fingerprints gave him away, while in his posthumous memoir, Jarvis says "two address books" found on Little enabled police to find him. (Malcolm X's autobiography, likewise, refers to "some papers they found on me.") Jarvis spoke fondly, never critically, of Malcolm in his two books and videotaped interviews. The Other Malcolm, 52, 132, 134; Malcolm Little and Malcolm L. Jarvis prison files, Department of Corrections, State of Massachusetts; The Autobiography of Malcolm X, 149; Malcolm L. Jarvis, Myself and I (n.p. [Boston], 1979); Strickland, Malcolm X: Make it Plain, 46, 48, 51, 54-59, 62-65, 67; Malcolm X: His Life and Work (Boston: Northeastern University and the University of Massachusetts at Amherst, n.d. [1993]). 
bitter rivals, and depicted Perry, inexplicably, as "a great admirer and defender of Malcolm X." Tatchell proposed to refashion Malcolm as a gay hero for Black History Month since "Elton John has no black equivalent." His last article, for The Independent, called Malcolm "bisexual, out, and proud." These interventions, although obviously not scholarly, influenced subsequent black studies discussions and helped to seal a perception that the issue was primarily one of sexual orientation. Inevitably, a "bi any means necessary" meme spread across the Internet, propelled by Tatchell's indubitable flare: "Malcolm X was bisexual. Get over it."39

Meanwhile, Manning Marable, at work on his own Malcolm X biography, was unearthing new shards. Papers once kept in the family home of Malcolm X's widow, Betty Shabazz, were acquired by the New York Public Library's Schomburg Center for Research in Black Culture in 2002. Contained in the trove was correspondence between the imprisoned Malcolm and his brother Philbert Little in Michigan, including a salient 1951 letter which Marable cited for the first time in his 2011 book: "A very wealthy man, for whom I once worked, visited me today and is going to try and get me a reconsideration from the parole board (Insha Allah). The will of Allah will be done. By the way, he's not an original. However, he can give me a home and a job, which is

\footnotetext{
${ }^{39}$ Peter Tatchell, "Malcolm X-gay black hero?" The Guardian, 19 May 2005, http://www.theguardian.com/world/2005/may/19/gayrights.usa ; Peter Tatchell, "Malcolm X was bisexual. Get over it," The Guardian, 20 Oct. 2009, http://www.theguardian.com/commentisfree/cifamerica/2009/oct/20/malcolm-x-bisexual-black-history ; "Peter Tatchell: Ignore the refuseniks—Malcolm X was bisexual, out, and proud," The Independent, 18 Feb. 2010, http://www.independent.co.uk/voices/commentators/peter-tatchell-ignore-the-refuseniksndash-malcolm-x-was-bisexual-out-and-proud-1902777.html .
} 
something I lacked when I saw them before." ("Not an original" meant not black in Nation of Islam idiom.) This letter, remarkably similar to that Malcolm wrote in 1946 to Ella Collins, was taken by Marable, plausibly, to also refer to Lennon. ${ }^{40}$

In Marable's book, indeed, the question of same-sexuality contracts wholly to Lennon, all other possibilities going unmentioned. This concentration was understandable given density of evidence, but other leads merited pursuit. Malcolm Little's draft evasion, for example, is according to legend a moment of race resistance when he threatened to turn his gun on white "crackers" if inducted. ${ }^{41}$ His FBI file, though, ascribed the draft board's "psychiatric rejection" of Malcolm Little on October 25,1943 , to "sexual perversion" and "psychopathic personality," with no mention of race or threatened violence. ${ }^{42}$ His full psychological evaluation does not survive, but Selective Service records not cited elsewhere in Malcolm X scholarship confirm that he registered for the draft in New York City in 1943 when residing at 2460 Seventh Avenue, Apt. 31, in Harlem as an employee of Jimmie's Chicken Shack, and was

\footnotetext{
${ }^{40}$ The discovery is significant, but Marable overreaches by imbuing "home" with sentimental meaning. The phrase "home and a job" merely echoed the parole process's requirements, as in the file's very next letter, when Malcolm wrote his brother of his hope to join him in Michigan: "As you know, I see the parole board again in four months (May), and I may try to get paroled to Detroit. To do this I must have a job and a home there, and this information must be in the hands of the parole board here before I see them." Malcolm Little to Philbert Little, 19 Dec. 1951, and 15 Jan. 1952, box 3, folder 1, The Malcolm X Collection: Papers, Schomburg Center for Research in Black Culture, Manuscripts, Archives and Rare Books Division, New York Public Library.

${ }^{41}$ The Autobiography of Malcolm X, 105-107; Kelley, "The Riddle of the Zoot," 165-167.

42 "Malcolm X, Part 1 of 38, , FBI Vault, 44 out of 119, https://vault.fbi.gov/Malcolm\%20X/Malcolm\%20X\%20Part\%201\%20of\%2038/view.
} 
classified 4F-rejection for physical, mental, or moral reasons—early in 1944 following "psychiatric investigation." ${ }^{43}$ Khary Polk has rightly condemned the silence of Malcolm X scholars about homosexuality's pertinence in the determination of his draft status. ${ }^{44}$ Neither interracial sex nor prostitution steering, factors that Evanzz suggests may account for the phrase "sexual perversion," were among the military's indicators of "pathological personality types." ${ }^{45}$ War Department guidelines stated:

Sexual perversions.-Persons habitually or occasionally engaged in homosexual or other perverse sexual practices are unsuitable for military service and should be excluded. Feminine bodily characteristics, effeminacy in dress or manner, or a patulous rectum are not consistently found in such persons, but where present should lead to careful psychiatric examination. If the individual admits or claims homosexuality or other sexual perversion, he should be referred to his local board for further psychiatric and social investigation. If an individual has a record as a pervert he should be rejected. ${ }^{46}$

Revealingly, all the medical terminology and stereotypes mustered in this definition focus on homosexuality, despite the passing nod to "other perverse sexual practices." That, historians have found, is precisely how it functioned. ${ }^{47}$ The phrase "sexual

\footnotetext{
${ }^{43}$ Selective Service System file of Malcolm Little, National Archives and Records Administration, St. Louis, Missouri.

${ }^{44}$ Khary Polk, "Malcolm X, Sexual Hearsay, and Masculine Dissemblance," Biography, vol. 36, no. 3 (2013): 580 .

${ }^{45}$ Evanzz, The Judas Factor, 34; William C. Menninger, Psychiatry in a Troubled World (New York: Macmillan, 1948), 562-563.

46 “Mobilization Regulations: War Department, No. 1-9, Washington, March 15, 1942," in Neuropsychiatry in World War II: Volume I: Zone of Interior, ed. Col. Robert S. Anderson, et al. (Washington: Government Printing Office, 1966), 788-789.

${ }^{47}$ Historians of sexuality have long identified the Second World War as a turning point in homosexuality's bureaucratic definition and repression: Estelle B. Freedman, “'Uncontrolled Desires': The Response to
} 
perversion" in Malcolm Little's FBI file, thus, almost surely indicates declaration of same-sex encounters in order to evade conscription.

Had Marable not overlooked such leads, he might have persuaded more readers, but he and his research assistants did uncover more on William Paul Lennon than ever before. [INSERT FIGURE TWO NEAR HERE OR NEXT PAGE OR SO, DELETING THIS BRACKET] They determined Lennon was born in 1888 (meaning he would have been in his late fifties when he began interacting with Malcolm Little), was the eldest of eight children of a successful merchant and newspaper publisher in Pawtucket, Rhode Island, attended Brown University for several years, was a naval officer in the First World War, and served as a hotel manager. These were valuable details, but a great deal more about Paul Lennon awaited discovery. ${ }^{48}$

the Sexual Psychopath, 1920-1960," The Journal of American History, vol. 74, no. 1 (June 1987), 83-106; Allan Bérubé, Coming Out Under Fire: The History of Gay Men and Women in World War Two (New York: The Free Press, 1990); Margot Canaday, The Straight State (Princeton: Princeton, 2009). ${ }^{48}$ Two Marable points cannot be confirmed. First, he claims that "Rudy," powderer of the wealthy man in the Autobiography, was Malcolm, but he supplies no evidence for it. Jarvis's memory that Cooper and Little both took part makes "Rudy" seem more likely a composite. Secondly, Marable cites New York Times classified ads seeking a male secretary defined as a "personable young man with good background; some driving." He claims these were placed by Lennon, but the ads supply no name, merely stating Apt. 43, 5 Arlington St., Boston. Lennon shared that street address, but Lennon's specific apartment number is not provided in Boston city directories, Brown University records, Little's prison files, or any other known source. His hiring of Malcolm did not occur until two years later. New York Times, Oct. 2, 1942, C43; and Oct. 4, 1942, RE21. 
Lennon was wealthy, for example, a fact Marable was unable to verify. ${ }^{49}$ His prosperity came from his marriage to a socialite, born Jeanne Marie Scott, daughter of a Wall Street banker who in 1915 left her the bulk of an estate valued at $\$ 584,225$ ( $\$ 13.7$ million today). In her debutante days in New York, Newport, and Palm Beach, she was known as Mimi Scott. During the First World War she volunteered as a Red Cross nurse in France, where she had a well-publicized romance with Hobey Baker, a Princeton star athlete turned fighter pilot. When she broke off their engagement and Baker crashed his plane at war's end, it prompted speculation that he committed suicide out of heartbreak. This has not endeared her to his admirers and biographers, who describe her as "a good-looking girl in a flashy sort of way" but "hard" and "vacuous" with "no sweetness" and "no charm at all." She instead married Philander Lathrop Cable, a U.S. Embassy official in Paris, divorcing him a decade later in 1929 on "grounds of indifference and his formal refusal to live with her." In 1937, she married Paul Lennon in Palm Beach to become Jeanne Marie Lennon. According to their wedding notices, Lennon—once manager of hotels in Rhode Island, Florida, and New York, where he resided in Greenwich Village—was by then in "the commission business" in Paris. "The wedding of the couple came as a complete surprise to friends as no engagement was announced," one news account observed. They called themselves "Mr. and Mrs. Paul Lennon of Boston and Paris" until the Nazi conquest of France led to building a "permanent residence" at Cape Cod in Sandwich, Massachusetts. They continued to winter in Florida, she arriving early some years while he was "detained in the North on business."

\footnotetext{
49 "There is no record indicating that Lennon ever became truly wealthy": Marable, Malcolm X, 65.
} 
Their childless union appears to have dissolved in 1948, shortly after Malcolm Little's incarceration. ${ }^{50}$

${ }^{50}$ Jeanne M. Lennon was listed in the Sandwich, Massachusetts, town censuses of 1947 and 1948 but not the next, in 1953. Early in 1949, Paul Lennon arrived to "his home" in Palm Beach with no mention of her, as was their custom. By 1950, she was living under her maiden name, Jeanne Marie Scott, at a Park Avenue address, and embarking on annual trips to France. By 1958, she died, most likely in France since there is no U.S. record except for estate sales. William Paul Lennon died in Sandwich, Massachusetts, in 1964, and was buried in Pawtucket, Rhode Island. "Geo. I. Scott Dies Suddenly," New York Times, 31 Oct. 1915, 17; "George Isham Scott Left \$584,225," New York Times, 10 Nov. 1916, 13; "Ball at the Ritz for Miss Mimi Scott," New York Times, 31 Dec. 1913, 9; "Miss Mimi Scott's Wartime Romance," Philadelphia Inquirer, 27 Oct. 1918, 2; "Hobey Baker is Beaten in Battle with Cupid," Tulsa World, 8 Dec. 1918, 3; “'Hobey’ Baker Dies in Fall of Airplane,” New York Times, 27 Dec. 1918, 7; Emil R. Salvini, Hobey Baker: American Legend (St. Paul: The Hobey Baker Memorial Foundation, 2005), 107, 109; “Miss Mimi Scott Marries L. Cable," New York Times, 8 June 1919, 20; “Jeanne M. S. Cable Wed in Palm Beach," New York Times, 26 March 1937, 18; "Paul Lennons Give Palm Beach Party," New York Times, 11 April 1937; "Society Personals," Miami Herald, 26 May 1914, 2; “New Hotel Dorset Opens," New York Times, 22 Jan. 1927; “Former War Vessel a 'Floating Club’ Here,” New York Times, 23 June 1929; "Diplomat is Divorced," New York Times, 30 July 1929, 5; William Paul Lennon, Biographical File, Brown University Archives; "Jeanne M. S. Cable Wed in Palm Beach," New York Times, 26 March 1937, 18; "Paul Lennons Give Palm Beach Party," New York Times, 11 April 1937; "Society Personals," Miami Herald, 26 May 1914, 2; "New Hotel Dorset Opens," New York Times, 22 Jan. 1927; "Former War Vessel a 'Floating Club' Here," New York Times, 23 June 1929; William Paul Lennon, Biographical File, Brown University Archives; "Catches in the Social Stream," Palm Beach Daily News, 26 Mar. 1937, 2; Alison Arnold, "Boston Folk Attend Reception to Duke and Duchess of Windsor," Boston Herald, 28 April 1941, 9; "Social Activities in Full Swing in Palm Beach," The Boston Herald, 29 Jan. 1939, 4; "Palm Beach Notes," Palm Beach Post, 9 Jan. 1943, 2; Susan Lundquist (Assistant Town Clerk, Sandwich), e-mail to author, 24 July 2015; "Catches in the Social Stream," Palm Beach Daily News, 9 Jan. 1949, 2; “Elegance 
That Paul Lennon is the name by which Malcolm Jarvis and Ella Collins remembered him is significant, because he went by that rather than his full name. The apartment he kept at 5 Arlington Street on the Boston Common was supplemental to the primary residences he and his wife maintained in Palm Beach and Cape Cod, where they lived a life of leisure and charity, to judge by the society pages. Significantly, Lennon had a proclivity for hiring servants drawn from a rougher demographic to work for him at 5 Arlington Street. In 1943-the year prior to his hiring of eighteen-year-old Malcolm Little—a thirty-two-year-old houseman he discharged was arrested for stealing five of his suits and a topcoat worth $\$ 530$ ( $\$ 5,900$ today) and charging another suit to his department store account. ${ }^{51}$

A subsequent incident involving the rougher sort has also escaped the attention of scholars. In 1955, Lennon was rescued by police who found him gagged and tied in bed at his Sandwich home in the middle of the day, with two naked male domestic employees bound and lying on the floor in the same room. Lennon told the press he was sixty-four, a few years younger than his actual age, and he was identified in the front-page Boston Globe coverage as a "wealthy Florida businessman," not a Bostonian. (He last made use of 5 Arlington Street in 1948, to gauge by city directories.) It was reported that he was reading in bed when four gunmen in their twenties and thirties overpowered John I. Grant, his butler and chauffer, who had just "returned from the village post office with the morning mail," and Paul E. Chamberlain, his gardener,

on the Run," New York Times, 16 Feb. 1958, 50; "Arts and Antiquities Offered at Sales," New York Times, 13 April 1958, 124.

51 “Former Houseman Gets Threft [sic] Sentence," Boston Traveler, 1 Sept. 1943. 
both twenty-five, and "marched them into the bedroom, forced them to disrobe and lie on the floor and bound them." A later report stated, "After the gunmen left, Chamberlain knocked over a phone and called police." Preoccupied with the sensational theft of valuables worth $\$ 10,000$ ( $\$ 88,000$ today), the newspapers did not explain how a band of young Boston ex-convicts knew to target Lennon's Cape Cod home or why the criminals had made him and his young male household workers strip naked. ${ }^{52}$

Barring some yet-undiscovered revelation, two camps of understanding are likely to persist among scholars. One will continue to talk of Malcolm Little's same-sex acts as "speculation," "conjecture," "rumor," and "hearsay," seeing the evidence as "not credible enough to really be able to measure it one way or the other. ${ }^{.53}$ The other will find the convergence of evidence more than hearsay and sufficient to indicate that Malcolm Little did at the very least participate in the talcum-powder rubdowns of Paul Lennon:

${ }^{52}$ One gunman, Gordon K. Stewart, 26, received mitigation in sentencing when Lennon testified that during the robbery he fed him a pill to alleviate his blood pressure. Conflicting reports put the ages of Grant as 34 and Chamberlain as 38 , but if he was 25, as one states, Grant might have been the same John I. Grant identified in the 1930 census as a Negro born in West Palm Beach, Florida. " $\$ 10,000$ Holdup on Cape Cod," Boston Globe, 11 Aug. 1955, 1; "Cape Police Hunt Bandits In \$10,000 Home Looting," Boston Traveler, 14 Aug. 1955; “\$60,000 Holds Hub Trio,” Boston Daily Record, 17 Sept. 1955, 12; United States of America, Bureau of the Census, Fifteenth Census of the United States, 1930 (Washington: National Archives and Records Administration); "Wounded Convict Hunted, Pals Held," Boston Evening American, 13 Aug. 1955; "Bandit's Heart Pill Aids Holdup Victim," Boston Daily Record, 13 Aug. 1955.

53 "Not credible enough": "Jared Ball Interview with Zak Kondo, April 11, 2011," in A Lie of Reinvention, 230; contributors to the book employ the other words with frequency. 
The Autobiography of Malcolm X passage about the "blueblood, pillar-of-society aristocrat" who climaxed if a naked young man undressed him and sprinkled him with talcum powder; Malcolm Jarvis's attestation that Malcolm said he powdered and rubbed down "the queer" Paul Lennon; Ella Collins's statement that Malcolm told her of a "business deal" involving Lennon, "one of those decadent whites whom he had been hustling"; the two handwritten letters from Malcolm in prison, one to Collins in 1946, the other to his brother in 1951, indicating a "very wealthy man, for whom I once worked" whose name is in "the society pages" might support his parole; the prison file stating Malcolm's employment by Lennon as butler and household worker; and authentication here of Lennon's wealth and recurrent association with young male toughs. Those in this camp might credit, as well, the fellatio story of Bob Bebee, Perry's additional episodes from the Harlem YMCA to the Flint boarding house, or the Selective Service "sexual perversion" designation. If the first view seems to insist on a photograph or direct statement by Malcolm as proof, the second will observe that the amassed evidence is very difficult to explain in any other way, that history often entails probability, and that historians of sexuality in particular often rely on inference given the lacunae left by discretion and erasure compelled by social stigma. There is no purity of method in these respective approaches, though, for as the historian Clarence Lang has observed, many who insist on categorical proof in regard to Malcolm's sexuality are perfectly open to inference and probability when it comes to whether government agencies were involved in his assassination. ${ }^{54}$

\footnotetext{
${ }^{54}$ Clarence Lang, "Manning Marable and Malcolm X: The Power of Biography," Against the Current, whole no. 154 (Sept./Oct. 2011), 21-24.
} 
For those who find the evidence of same-sexuality sufficient, what remains to be determined is its meaning. This requires sensitivity to acts, roles, and context. Virtually all who have written about the question presume that if Malcolm Little participated in same-sex acts it automatically determines his emotional involvement, sexual orientation, or sexual identity. ${ }^{55}$ When Lennon hired him, writes Marable, "soon something deeper than an employer-employee relationship developed," an "intimate relationship" that made Malcolm a "homosexual lover," even if not one "actively homosexual" in later years. Such phrases are precisely what most riled others, such as Patricia Reid-Merritt, who called them "direct attacks on Malcolm's manhood." ${ }^{\text {"56 }}$ Quite apart from their moral tonality, each of these positions is profoundly anachronistic, for neither shows awareness that in the 1930s and 1940s it was possible for a man to engage in sex with another and yet be considered heterosexual and manly, particularly in poor and working-class culture and in the hustler world.

The importance of two works to understanding this lost world of sexual consciousness cannot be overstated: George Chauncey's Gay New York (1994) and Barry Reay's New York Hustlers (2010). Chauncey charted a varied and gendered Depression-era sexual culture of effeminate "fairies" and "pansies," predatory "wolves" seeking young "punks," middle-class "queers," and—crucially_-trade," heterosexual men who neither identified nor were perceived as homosexuals but were open to samesex invitations. A "phallocentric economy of sexual pleasure," he explained, put male

${ }^{55}$ One excellent, brief exception is Kevin McGruder, "Our Malcolm, Ourselves," in By Any Means Necessary, ed. Boyd et al, 230-234.

${ }^{56}$ Marable, Malcolm X, 65-66, 78, 96; Patricia Reid-Merritt, "Malcom X: What Measure of a Man?" in A Lie of Reinvention, 30. 
gratification above sexual object-choice, although by 1940 a modern gay male identity, patterned on that of discreet middle-class queers, coalesced to eclipse the earlier ways of being. Reay's study extends this timeline past the Second World War, proving with copious pictorial-textual detail that trade persisted throughout the 1940 s and beyond. ${ }^{57}$

References to straight trade abound in reminiscences of the 1930s and 1940s. One man recalled Hearst newspaper columnist Maury Paul's kept boy in Manhattan: "The handsomest man I had ever seen... It was trade Maury had picked up, polished up, dressed up. Straight." Chuck Rowland, a Mattachine Society founder, said of a good friend in the Army during the Second World War, "He wasn't gay although we had sex a couple times." Likewise, Samuel Steward recalled sexual encounters in Chicago from the 1930 s to the 1950 s with hundreds of heterosexual men: "It was more natural to them just to get their rocks off any way they could. And it didn't matter a whole hell of a lot whether it was male or female. A man enjoyed a good blow job just as much as he did a good screw. The only kind of censure that there was seemed to be connected with anal screwing. If a man let himself be screwed, then it was a step downward and he was subject to a lot of razzing or insult. But, when the mouth was used, it didn't seem to be important at all." Bathhouse patrons, Steward said, included "a lot of straight guys" open to mutual masturbation and the 1940s' "language of love": "How'd you like to have your cock sucked, Buddy?"58

\footnotetext{
${ }^{57}$ George Chauncey, Gay New York: Gender, Urban Culture, and the Making of the Gay Male World, 1890-1940 (Chicago: Chicago, 1994), 83; Barry Reay, New York Hustlers: Masculinity and Sex in Modern America (Manchester: Manchester, 2010).

${ }^{58}$ Charles Kaiser, The Gay Metropolis (San Diego: Harcourt, Brace, 1997), 10; Chuck Rowland interview, August 22, 1989, Eric Marcus Papers, New York Public Library Manuscripts, Archives, and Rare Books
} 
The concept of straight trade-sometimes called "rough trade" if the partner was a working-class tough—makes intelligible the otherwise baffling utterances of those interviewed by medical doctor George W. Henry for Sex Variants: A Study of Homosexual Patterns (1941). One said, "Sometimes I have relations with heterosexual men, but the homosexuals are better." Another, with opposite tastes, described his "ideal sexual object": "He must have no suggestion of homosexuality about him. ...A person defiant of convention, ruggedly individualistic, independent, frank, slightly coarse, even slightly brutal, outspoken, strong minded, virile in every way is preferred." One man interviewed by Chauncey struggled to explain the 1930s and 1940s: "A lot of straight boys let us have sex with them. People don't believe it now. People say they must have been gay. But they weren't. They were straight. They wouldn't look for or suck a guy's thing, but they'd let you suck theirs. If you want to say they were gay because they had sex with a man, go ahead, but I say only a man who wants to have sex with a man is gay." As late as 1965, The Guild Dictionary of Homosexual Terms defined trade as "the male of masculine body type and build, usually heterosexual, who takes the positive, leading, inserter role in sexual relations with the homosexual..." The pioneering gay historian Allan Bérubé acknowledged straight trade, writing that in the first half of the twentieth century, "Many men who came out...had learned to prefer 'servicing' straight men in semipublic places." 59

Division; Len Evans interview of Samuel Steward, 1983, published as Terence Kissack, "Alfred Kinsey and Homosexuality in the "50s," Journal of the History of Sexuality, Vol. 9, No. 4 (Oct. 2000), 482, 487. ${ }^{59}$ George W. Henry, Sex Variants: A Study of Homosexual Patterns (1941; London: Cassell,1952), 3637, 155, 346, 378-379; Chauncey, Gay New York, 21-22; dictionary quoted in Reay, New York Hustlers, 
Trade helps make sense of the sexuality of Malcolm Little, who had none of the characteristics of the "fairy," "pansy" or "queer." Attraction to the opposite sex suffuses The Autobiography of Malcolm X and all other evidence. In Lansing, he recalled, "I really went for some of the white girls, and some of them went for me, too." In his zoot suit and conk years in Boston, he went lindy-hopping at the Roseland, "whirling girls so fast their skirts were snapping," boosting them "over my hips, my shoulders, into the air." He was involved with black women such as "Laura" (Gloria Strother) and white women such as his girlfriend and accomplice in crime "Sophia" (Beatrice Caragulian), and pursued by women less often remembered, such as the shapely Jaci Massey, who brought him home-cooked food in prison. "I met chicks who were as fine as May wine," he recounted, "and cats who were hip to all happenings." His scrawled youthful letters, written in a juvenile script, abound in sly flirtations, invariably with women. "Listen, will you send me a picture of you," he wrote one in Michigan in 1941 after asking whether she was still seeing someone else. "I want to show the fellas out here that we have some fine girls in Michigan too \& I want pictures of only the finest 'no jive.' "60

That such a connoisseur of "only the finest" women could also have had samesex encounters is perfectly credible. An initial analytical distinction must be made between the masturbation and fellatio with Robert in the Lansing woods relayed by

12; Allan Bérubé, My Desire for History: Essays in Gay, Community, and Labor History (Chapel Hill: University of North Carolina, 2011), 71.

${ }^{60}$ The Autobiography of Malcolm X, 30, 56, 58-59; Malcolm Little to "Dearest Pal," 18 Nov.1941, box 1, folder 15, Malcolm X Papers, Charles H. Wright Museum of African American History, Detroit. On Massey: Collins, Seventh Son, 65-66; and Malcolm Little to Ella Collins, 14 Dec. 1946, and 28 Mar. 1948, box 1, folders 16-17, Malcolm X Papers, Wright Museum. 
Bebee and the subsequent episodes, for that occurred in early adolescence, its exhibitionism and group activity consistent with Alfred Kinsey's contemporaneous finding in Sexual Behavior in the Human Male (1948) that "many a boy exhibits his masturbatory techniques to lone companions or to whole groups of boys," almost half taking part in "mutual manipulation of genitalia."61 Boys' greater access to one another in adolescence explained this, Kinsey wrote; such experimental sex play did not determine adult sexual orientation.

A gender analysis is essential to comprehension of both that and the four later cases: Willie Mae (Flint), Reverend Witherspoon (Harlem), Jimmy Williams (Lansing), and Paul Lennon (Boston). In each instance, Malcolm occupied a masculine position, whether in contrast to the "effeminate" and "sissy" Robert, Willie Mae with his bright yellow jumper, the theatrically self-named Reverend Witherspoon and other YMCA "queers," the 240-pound "homosexual" Jimmy Williams, or the wealthy Paul Lennon, whom Jarvis called "the queer." Not only were these sexual partners or queer acquaintances less masculine, they were female. Willie Mae is "Miss Jones," Malcolm paid visits to "little girls" at the YMCA, and Jarvis referred to "Mrs." Paul Lennon. Insofar as specific acts are described, Malcolm is fellated rather than fellator, masturbated rather than masturbator, and powderer rather than powdered, correlating to a sexual ideology of dominance and submission, penetrator and penetrated, trade and queer, male and female—with Malcolm on the "manly" side of every antinomy.

The four later encounters all took place from 1943 onward, when Malcolm Little was drifting restlessly between homes and states, edging ever more deeply into

${ }^{61}$ Kinsey, 168-171. 
hustling, dealing marijuana, and using cocaine, amphetamines, and opium. These were his hustler years as "Big Red" (or "Detroit Red" in the autobiography), spent mostly in Harlem in 1943-45 and Boston in 1945-46. "Almost everyone in Harlem needed some kind of hustle to survive," he states in the Autobiography, "and needed to stay high in some way to forget what they had to do to survive." All of the encounters entailed material reward, whether rent (Willie Mae), a chicken dinner (Reverend Witherspoon), housing (Jimmy Williams), or money (Paul Lennon). His hustler masculinity, as Douglas Taylor has perceptively argued, deserves to be distinguished from his zoot-suit frenzy of 1941-43, for the hustler pose was "cool," the dress style more conservative (when moving a brick of weed, an attention-getting zoot was a liability), and the mindset more callous in which women, particularly white women, were commodities and manhood was defended in "showdowns" against any who might threaten it. Bill Fletcher finds the possibility that Malcolm "engaged in a same-sex encounter for pay" useful to explain "the criminal, parasitic life that Malcolm Little lived prior to prison," yet few others have been willing to entertain the idea that Malcolm's urbane hustler masculinity not only governed him as reefer pusher, prostitution steerer, and numbers runner but also in sexuality with men—-that being seen as merely of "salacious interest." ${ }^{\text {"2 }}$

${ }^{62}$ The Autobiography of Malcolm X, 91; Douglas Taylor, "Showdown: Symbolic Violence and Masculine Performance in The Autobiography of Malcolm X (As Told to Alex Haley)," Men and Masculinities, vol. 11, no. 5 (Aug. 2009), 558-577; Bill Fletcher, "Manning Marable and the Malcolm X Biography Controversy," in By Any Means Necessary, 125, 129; Imani Perry, “'Malcolm X,' by Manning Marable," San Francisco Chronicle, 23 April 2011, http://www.sfgate.com/books/article/Malcolm-X-by-Manning-Marable2373944.php . 
The chapter of The Autobiography of Malcolm X entitled "Hustler" has always seemed to refer to his life as a thief and dope dealer, but as a homonym the word can mean a go-getter, a con artist, a criminal—or a male prostitute. In this last sense, hustling was coextensive with trade. One interviewee in George Henry's Sex Variants spoke of trade that "is heterosexual and prefers women but will sell his body to anyone for money," and Henry in an earlier article described the "hoodlum" hustler who has "a rough, aggressive, 'hard-boiled' exterior," boasts "a little of the 'fags' he has beaten and robbed," and often supplements his earnings "by assault and robbery of the clients or possible benefactors." Malcolm derogated "queers," held up Jimmy Williams at gunpoint, and robbed Lennon's apartment with his Boston burglary ring. Lennon himself was to type, for according to Steward those most likely to use hustlers were "wellheeled older persons," especially closeted gay men. One such patron said, "Two years ago I met a male prostitute in Times Square. He was just what I wanted—big, athletic...about twenty-five years old. I detest homosexual boys." ${ }^{\prime 63}$

It is far more economical to see Malcolm as rough trade hustling Lennon, including when seeking parole, than as a "homosexual lover" in an "intimate relationship." In the history of sexuality, it is an axiom that sex acts and sexual identity are distinct. The erotic proclivities of a client—say, an older closeted white man's fetish for soft white powder sprinkled on him by naked black bodies, inverting class and race norms with a stereotype-fueled frisson of danger-in no way indicates the paid

${ }^{63}$ Henry, Sex Variants, 36-37, 154-155, 346, 378-379; George W. Henry, "Social Factors in the Case Histories of One Hundred Underprivileged Homosexuals," Mental Hygiene 22 (1938), 606; The Autobiography of Malcolm X, 143; Sam Steward, Understanding the Male Hustler (New York: Harrington Park, 1991), 68-71, 74; James Baldwin, Giovanni's Room (1956; London: Michael Joseph, 1964), 112. 
performer's romantic-emotional involvement or sexual desire.$^{64}$ Trade had leverage, for as James Baldwin wrote, the hustler was "a good deal less frightened than the men who roamed the streets to buy them, whose careers, positions, aspirations, could never have survived such notoriety." The midcentury social science on hustlers found them, just as was Malcolm Little, to be between fifteen and twenty-three years of age and from "broken homes." They did not see themselves as queer or effeminate if brought to orgasm by another man so long as they were the inserter: "only a few will admit any pleasure from homosexual relations and most say that they find them repulsive"; "among male hustlers...one who has the reputation of being mainly heterosexual is more desired"; "he regarded 'what happened' as a form of masturbation: he would close his eyes and think about 'girls and things' "; "the boy develops no self-conception as a homosexual person"; "hustlers are not necessarily homosexual, and many of them will characterize themselves as heterosexual." One in-depth sociological study found most male prostitutes to be trade, not bisexuals who "recognize their homosexual activity as indicative of their own psychosexual orientations." ${ }^{65}$

\footnotetext{
${ }^{64}$ For a pertinent exposition, see Noah D. Zatz, "Sex Work/Sex Act: Law, Labor, and Desire in Constructions of Prostitution," Signs, vol. 22, no. 2 (winter 1997), 277-308.

65 James Baldwin, Giovanni's Room (1956; London: Michael Joseph, 1964), 112; William Marlin Butts, "Boy Prostitutes of the Metropolis," Journal of Clinical Psychopathology, vol. 8, no. 4 (April 1947), 674; "H. Laurence Ross, "The 'Hustler' in Chicago” (unpublished mimeo mss. [1958?], Loeb Library, Harvard University); Simon Raven, "Boys Will Be Boys," Encounter, vol. 15, no. 5 (Nov. 1960), 20; Albert J. Reiss, Jr., "The Social Integration of Queers and Peers," Social Problems, vol. 9, no. 2 (fall 1961), 102; Robert W. Deisher, et al., "The Young Male Prostitute," Pediatrics, vol. 43, no. 6 (June 1969), 936; Laud Humphreys, Tearoom Trade (London: Gerald Duckworth, 1970), 47, 121.
} 
Evidence abounds that in the 1930s and 1940s young heterosexual men often serviced homosexual clients, just as female prostitutes could be lesbians servicing men. ${ }^{66}$ One aficionado of trade in New York and Washington was Henry Gerber, credited with establishing the first American gay rights organization. "Boys and men who prostitute themselves to homosexuals for money," he wrote in 1946, "are almost always heterosexual[s] who care nothing for the homosexual except his money." ${ }^{67}$ In Tom Kramer's proletarian roman-à-clef Waiting for Nothing (1935), the protagonist accepts the advances of a "rouged" and "perfumed" man, "Mrs. Carter," because "a stiff has got to live": "These pansies give me the willies, but I have got to get myself a feed." ${ }^{68}$ This phenomenon was transatlantic. A Danish study of 300 adolescent prostitutes found $85 \%$ to be heterosexual, $12.7 \%$ bisexual, and $2.3 \%$ homosexual, while in London male prostitutes were "primarily heterosexual" and "likely to spend their best energies, as well as their immoral earnings, upon girlfriends." 69

Malcolm Little showed no trace of homosexual or bisexual orientation. No morals charge appears on his otherwise extensive rap sheet. His same-sex hustling appears to have been an opportunistic sideline, and an entirely unsurprising one given the informal economies of Harlem and Roxbury, where race and sexuality converged as redlining,

\footnotetext{
${ }^{66}$ On contemporaneous lesbian prostitutes, see for example, Ben L. Reitman, Sister of the Road: The Autobiography of Box-Car Bertha (New York: Sheridan House, 1937): 66, 69-70.

${ }^{67}$ Henry Gerber to Leopold Wexburg, 18 July 1946, box 44, Jonathan Ned Katz Papers, New York Public Library Manuscripts, Archives, and Rare Books Division.

${ }^{68}$ Tom Kromer, Waiting for Nothing (New York: Knopf, 1935): 59, 61, 72.

69 Jens Jersild, Boy Prostitution (Copenhagen: C. E. Gad, 1956), 7, 59; D. J. West, Homosexuality (1955; Harmondsworth: Penguin, 1968), 130.
} 
vice enforcement, and white middle-class "slumming" fads shaped urban space in the first half of the twentieth century, with racism accentuating forbidden desire.$^{70}$ Malcolm's same-sex transactions, like his other illicit hustles, supplemented low-wage proletarian drudgery (jobs were "slaves"), enabled evasion of military racism, and underwrote a life of highs and jazz in the clubs. "I was a true hustler-uneducated, unskilled at anything honorable," he told Alex Haley, "and I considered myself nervy and cunning enough to live by my wits, exploiting any prey that presented itself." ${ }^{\prime 11}$ A friend from Harlem days, Clarence Atkins, said, "He was just wild, man. He didn't give a shit about nothing... Whatever he thought was the thing for him to do at a particular time, that's what he would do." ${ }^{72}$

When Malcolm Little became Malcolm X [INSERT FIGURE THREE NEXT PAGE OR SO, DELETING THIS BRACKET], the transformation was born of the perception that his hustler self-image was delusory, that the criminal life made him prey, that he had sunk into "more and more, worse and worse, illegality and immorality." ${ }^{\text {73 }} \mathrm{His}$ religious conversion in prison coincided with the postwar shift in American sexual

\footnotetext{
${ }^{70}$ Kevin J. Mumford, Interzones: Black/White Sex Districts in Chicago and New York in the Early Twentieth Century (New York: Columbia, 1997); Chad Heap, Slumming: Sexual and Racial Encounters in American Nightlife, 1885-1940 (Chicago: Chicago, 2009); Kevin McGruder, "Pathologizing Black Sexuality: The U.S. Experience," in Black Sexuality: Probing Powers, Passions, Practices, and Policies, ed. Juan Battle and Sandra L. Barnes (New Brunswick: Rutgers, 2009), 101-108.

${ }^{71}$ The Autobiography of Malcolm X, 108.

${ }^{72}$ Quoted in De Caro, On the Side of My People, 64.

${ }^{73}$ The Autobiography of Malcolm X, 109.
} 
consciousness toward "normality" and defining one's sexual orientation by the biological sex of one's partner. ${ }^{74}$ As he excoriated "white devils" in the Nation of Islam, Malcolm X embraced normative fifties sexuality—marital, reproductive, heterosexual—and turned those norms against white society, decrying the history of white male lust and violence, especially rape of black women. The hustling life, he said, had given him insight into "the cesspool morals of the white man" and "the sick things he wanted." 75

To refute racist assumptions of black depravity, the Nation cultivated a puritanical-patriarchal moral code that preached respect toward women in the context of their subordination to men. Women were segregated at meetings, enjoined to dress modestly, and forbidden from dancing except with their husband. Nation adherents abstained from pork, alcohol, tobacco, drugs, gambling, profanity, and "fornication," including extramarital sexuality and homosexuality. If this mandated a sharp behavioral turnaround for Malcolm, its gender conservatism was continuous with his past sexism, its heterosexism with his statements of contempt for the homosexuals he hustled. Malcolm X's forceful rhetoric and advocacy of armed self-defense, which so excited white journalistic sensationalism, bear comparison with the performative "potential for violence" and "possibility of sudden death" in rough trade, which one New York hustler recalled provided patrons with "intensity" and "excitement" to "animate the eroticism."

\footnotetext{
${ }^{74}$ Anna G. Creadick, Perfectly Average: The Pursuit of Normality in Postwar America (Amherst: University of Massachusetts, 2010), 90-117.

75 “Playboy Interview: Malcolm X," Playboy, vol. 10, no. 3 (May 1963), 60.
} 
The transgressive antiracist politics of Malcolm X, this is to say, owed something tacitly to the transgressive interracial sexuality of Malcolm Little. ${ }^{76}$

Malcolm X's first act of protest as a Nation of Islam member occurred in prison, when he wrote the commissioner of the Massachusetts Department of Corrections to object to religious persecution of black Muslims. "Yet," he objected, "the homosexual perverts in here can get job-changes whenever they work to change or acquire new 'husbands.",77 That sentence, with its distinction of homosexuals from their husbands, took for granted a gendered male world in which same-sexuality did not automatically make one homosexual; simultaneously, it equated homosexuality with perversion. Nobody—including Jarvis, who entered prison with him in 1946—would claim that Malcolm X ever engaged further in homosexual acts as he forged new identities as believer, minister, husband, and father. None are noted in his prison file, and his daughter Ilyasah Shabazz and follower Peter Bailey have posited that as Malcolm X he was under surveillance so heavy that such activity would hardly have escaped the government's notice. ${ }^{78}$

\footnotetext{
${ }^{76}$ Dotson Rader, Gov't Inspected Meat and Other Fun Summer Things (New York: David McKay, 1971): 191.

${ }^{77}$ Malcolm Little prison file, Department of Corrections, State of Massachusetts.

78 "Malcolm X's Daughter Disputes Claims in New Bio on Father," April 20, 2011 http://www.npr.org/2011/04/20/135570322/malcolm-xs-daughter-addresses-controversial-claims-in-newbio-on-father ; Peter Bailey interviewed by Stephen Tuck, "I Literally Laughed When I Read It," Journal of American Studies, vol. 47, no. 1 (Feb. 2013), 45.
} 
In Malcolm X's simultaneous adoption of sexual conservatism and black militancy lies the line of continuity to the Black Power outlook that hailed him for "reclamation of the black man's masculinity." ${ }^{179}$ Malcolm was the archetype of the sixties opposition to the "castration" of a white world that called black men "boy," depriving them of "manhood." By the time Malcolm X worked on his autobiography with Alex Haley, to acknowledge same-sex encounters would have destroyed a credibility fashioned for that era's heteronormativity even as the toughness that made him alluring as trade was central to his radical charisma. His street appeal, as Sonia Sanchez expressed it so well, was gendered: "He said it in a very strong fashion, a very manly fashion, one that says, 'I am not afraid to say what you've been thinking all these years.' That's why we loved him so very much. He took on America for us."

Reticence today about discussing Malcolm's sexuality traces in part to emulation of this strategy of respectability, street credibility, and manliness. Even at his nationalist apex, however, Malcolm X had more than one side to him when it came to gender and sexuality. When $\mathrm{FBI}$ agents visited his home in 1964, he taped the ensuing conversation, including his casual slur against Bayard Rustin as a "homo," but in their public debates Malcolm respected Rustin—and he outright admired James Baldwin. ${ }^{81}$

\footnotetext{
${ }^{79}$ Wyatt Tee Walker, "Nothing but a Man," in Malcolm X: The Man and His Times, 64. Black nationalism in the United States bears comparison in this respect with European nationalism: George Mosse, Nationalism and Sexuality: Respectability and Abnormal Sexuality in Modern Europe (New York: Howard Fertig, 1985).

${ }^{80}$ Sanchez in Malcolm X: Make it Plain, 231.

81 "A Visit from the FBI," in Malcolm X: The Man and His Times, ed. Clarke, 201. On Baldwin, see Benjamin 2X's comments in Spike Lee, Malcolm: By Any Means Necessary (London: Vintage, 1993), 37.
} 
The extraordinary transformations of his final year from 1964 to 1965 included dropping objection to interracial relationships and hints of a proto-feminism, but when Malcolm X was gunned down at age thirty-nine, the world was only on the cusp of the late sixties' profusion of sexual, gender, and political radicalisms, including the gay and women's liberation movements. ${ }^{82}$

Care must therefore be taken to guard against anachronism, but the reminder that not all same-sexuality correlates with gay identity should be understood to complement, not deny, the growing black gay male historiography. ${ }^{83}$ To locate Malcolm's same-sexual encounters of the 1930s and 1940s within a culture that understood them as masculine and therefore heterosexual is not to "normalize" them but to historicize them. Rough trade was neither gay nor normative; interracial sexuality contravened propriety; hustling abrogated the law. Straight trade bears comparison to

${ }^{82}$ On Malcolm X and women, see Kibibi V. Mack-Williams, "Malcolm X and the Woman Question," Abafazi, vol. 1, no. 1 (spring 1991), 9-13; Barbara Ransby and Tracye Matthews, "Black Popular Culture and the Transcendence of Patriarchal Illusions," Race and Class, vol. 35, no. 1 (July 1993), 57-68; Farah Jasmine Griffin, "“Ironies of the Saint': Malcolm X, Black Women, and the Price of Protection,” in Sisters in the Struggle: African American Women in the Civil Rights-Black Power Movement, ed. Bettye CollierThomas and V. Franklin (New York: NYU, 2001), 214-229; Russell J. Rickford, Betty Shabazz: Surviving Malcolm X (Naperville, III.: Sourcebooks, 2003); and Sheila Radford-Hill, "Womanizing Malcolm X," in The Cambridge Companion to Malcolm X, 63-77.

${ }^{83}$ Space prohibits citation of this vast literature, but start with Kevin J. Mumford, Not White, Not Straight: Black Gay Men from the March on Washington to the AIDS Crisis (Chapel Hill: University of North Carolina Press, 2016), which is invaluable despite the errors in its small segment on Malcolm X, such as referring to William Paul Lennon as "Dennis Newman" and attributing to him a statement made by Malcolm Jarvis (p. 79). 
today's African-American "down-low"—ostensibly straight men having secretive sex with other men—but differs from the down-low's associations with bisexuality and the closet. ${ }^{84}$ Likewise, the queer, trans, and non-binary valences of millennials share little with the rigidly gendered culture that produced straight trade, but it is intriguing that there are survivals (or even signs of a revival) of disaggregation of identity from sexual activity, as in an oral history of steelworkers in which gay men report with some regularity having had workplace sex with working-class heterosexual men, or a poll that ten percent of young American heterosexuals have had a sexual encounter with someone of the same sex. ${ }^{85}$ If Malcolm Little's experiences must be understood in the categories of the 1930s and 1940s, this suggests that they are not entirely remote from our own. As Irene Monroe has astutely observed, "If we, as LGBTs, use this era of Malcolm's life to claim him as gay, we misunderstand the art and survival of streethustling culture. ...If we, as African Americans, use this era of Malcolm's life to dismiss that he engaged in same-sex relationships, many will miss the opportunity to purge ourselves of homophobic attitudes." ${ }^{86}$

${ }^{84}$ J. L. King, On the Down Low: A Journey into the Lives of Straight Black Men Who Sleep With Men (New York: Harmony, 2005).

85 "A third of young Americans say they aren't 100\% heterosexual," YouGov, 20 August 2015, https://today.yougov.com/news/2015/08/20/third-young-americans-exclusively-heterosexual/ ; Anne Balay, Steel Closets: Voices of Gay, Lesbian, and Transgender Steelworkers (Chapel Hill: University of North Carolina, 2014).

${ }^{86}$ Rev. Irene Monroe, "Malcolm X was 'gay for pay,"' Windy City Times, 13 April 2011, 18. Regrettably, this brief, excellent article was not included in either of the collections of responses to Marable. 


\begin{abstract}
AUTHOR BIOGRAPHY
Christopher Phelps, associate professor of American Studies at the University of Nottingham, is co-author of Radicals in America: The U.S. Left since the Second World War (2016) with Howard Brick. The Martin Duberman Visiting Fellowship facilitated research at the New York Public Library, and perceptive criticism is gratefully acknowledged from Angela Dillard, Martin Duberman, Anne Gray Fischer, Brett Gadsden, Joshua Hollands, Matthew Jones, Clarence Lang, Scott McLemee, Russell Rickford, Nick Witham, this journal's editors, Celeste-Marie Bernier and Bevan Sewell, and several anonymous referees. The author alone is responsible for all judgments. Dedicated in memory of Joe Wood (1964-1999).
\end{abstract}

